\title{
Features of the formation of the immune status in calves with different methods of feeding with colostrum
}

\author{
Sergey Karamaev ${ }^{1, *}$, Anna Karamaeva ${ }^{1}$, and Larisa Bakaeva ${ }^{2}$ \\ ${ }^{1}$ Samara State Agricultural University, Uchebnaya St., 2, Kinel, Samara region, 446442, Russia \\ ${ }^{2}$ Orenburg State Agricultural University, Chelyuskintsev St., 18, Orenburg, 460795, Russia
}

\begin{abstract}
The features of different methods of feeding calves with colostrum and their influence on the growth, development and health of young animals have been studied in a comparative aspect. The studies were carried out using newborn Holstein heifers at a modern dairy complex. Depending on the method of feeding, the calves consumed different amounts of colostrum on the first day: with a suckler mother cow - 10.8 liters, when using a suckling bottle and a nipple pail - 8 liters, using the CalfDrencher system - 7 liters. Different volumes and rates of colostrum entry into the digestive system of newborns had a significant impact on its digestion in calf abomasum and the transition of immunoglobulins into blood serum. It was found that only with the sucking method, 6 hours after drinking the first portion of colostrum, the content of immunoglobulins in the blood serum of calves was more than $10 \mathrm{mg} / \mathrm{ml}$, which corresponds to the physiological norm. In accordance with the intensity of the transfer of immunoglobulins from colostrum to blood serum, cases of disease in calves were distributed in the first month of life, which affected their further growth and development. As a result, the live weight required for the first insemination (at least $420 \mathrm{~kg}$ ) was achieved by the Holstein heifers in group I at the age of 16 months, in group II - 18 months, in group III - 17 months, in group IV - 19 months.
\end{abstract}

\section{Introduction}

During the natal period, being in the mother's body, the calf is completely protected from the unwanted effects of various factors due to the functional characteristics of the placenta. Therefore, it is born "sterile" and, at the same time, is completely devoid of any protective mechanisms in order to independently resist the negative effects of aggressive environmental conditions and pathogenic microflora. In this regard, the protective function in the body of the newborn is performed by colostrum, which, along with the main nutrients, contains immunoglobulins - antibodies that suppress the action of pathogenic microflora that entered the main life support systems of the calf at birth [1, 2, 3, 4].

\footnotetext{
* Corresponding author: KaramaevSV@mail.ru
} 
Under natural conditions, the calf receives colostrum by sucking it from the mother's udder. Colostrum of optimum temperature of $+38.5 \ldots+39.0^{\circ} \mathrm{C}$ enters the oral cavity, where it mixes evenly with saliva, as a result of which, under the influence of the chymosin enzyme, a loose clot of calcium caseinate is formed in the abomasum, which contributes to its better digestion $[5,6,7]$.

The intensification of dairy farming, based on maximum mechanization and automation of technological processes, also makes significant adjustments to the technology of raising newborn calves. Improvement of breeds in the area of increasing milk productivity, pursuit of increasing the marketability of milk, flourishing urbanization - all this prompts scientists and specialists to develop new methods and equipment for feeding calves with colostrum and milk in order to increase the efficiency of rearing young animals and the profitability of milk production in general $[8,9,10,11]$.

In this regard, the main task of research is to study, in a comparative aspect, various methods of feeding calves with colostrum and their influence on the growth, development and health of young animals.

\section{Materials and methods}

The research was carried out at a modern complex for the production of milk of Radna LLC in the Samara region. From newborn calves (heifers) of the Holstein breed, obtained from cows after the third calving, four groups were formed, 15 heads each: Group I - keeping on regulated suckling under nursing cows up to 2 months of age; II, III, IV groups - keeping in individual houses up to 2 months of age, drinking colostrum and milk in group II from a suckling bottle, in group III - from a nipple pail, in group IV - on the first day, colostrum was injected into the abomasum using the CalfDrencher device in a volume of 3.5 liters with an interval of 6 hours, from the second day of life - drinking from a nipple pail, 2 liters three times a day with an interval of 6 hours. The first 5 days, the mother's colostrum was fed to the calves, then the milk collected from healthy cows.

Average colostrum samples were taken before each feeding. In the research laboratory of animal husbandry of the Samara State Agrarian University and the analytical laboratory of the Orenburg State Agrarian University, the chemical composition of each sample was determined according to generally accepted methods. The content of immunoglobulins (Ig) in colostrum was determined using a digital refractometer "PAL-Colostrum", in the blood serum of calves - using a FEC-456M device. The calves were weighed monthly on a TAXATRON electronic balance.

According to the research results, the intensity of the transition of immunoglobulins from colostrum to the blood serum of calves was determined, in the first 6 hours after feeding every hour, then after 12, 24, 34, 48, 72 hours. All signs of health disorders were recorded in the calves of the experimental groups during the first month after birth.

\section{Research results}

The observation showed that when keeping newborn calves with their mothers, they sucked them 5-8 times during the first day of life, consuming on average from 1.3 to 2.2 liters of colostrum. Thus, the total consumption of colostrum by calves in the first day after birth with the sucking method was 10.6 liters, which is 2.6 liters more $(32.5 \%)$ than when drinking from a suckling bottle and a nipple pail and $3.61(51.4 \%)$ than with drenching (Table 1).

On the basis of numerous studies, the rate of drinking colostrum for newborn calves has been established. T. Mejer [6], I.R. Tizard [11], A.W. Scammell [12], S. Zarcula [13], A.K. 
Singh [14] found in their works that the optimal amount of immunoglobulins in the blood serum of newborn calves is observed when the size of the first portion of colostrum drunk is in the range of 1.5-2.0 liters. An increase in the rate of colostrum at the first feeding of more than 2.0 liters does not lead to an increase in immunoglobulins in the blood serum.

Table 1. Consumption of colostrum and immunoglobulins by Holstein calves in the first day after birth, depending on the method of feeding.

\begin{tabular}{|c|c|c|c|c|}
\hline \multirow[b]{2}{*}{ Indicator } & \multicolumn{4}{|c|}{ Method of feeding with colostrum } \\
\hline & $\begin{array}{l}\text { sucking } \\
\text { group I }\end{array}$ & $\begin{array}{l}\text { suckling bot- } \\
\text { tle } \\
\text { group II }\end{array}$ & $\begin{array}{l}\text { nipple pail } \\
\text { group III }\end{array}$ & $\begin{array}{l}\text { CalfDrencher } \\
\text { group IV }\end{array}$ \\
\hline $\begin{array}{l}\text { Volume of consumed } \\
\text { colostrum, } 1 \text { (sucking, } \\
\text { drinking): } \\
1^{\text {st }} \text { time }\end{array}$ & 1.3 & 2.0 & 2.0 & 3.5 \\
\hline $2^{\text {nd }}$ time & 1.8 & 2.0 & 2.0 & 3.5 \\
\hline $3^{\text {rd }}$ time & 2.2 & 2.0 & 2.0 & - \\
\hline $4^{\text {th }}$ time & 1.9 & 2.0 & 2.0 & - \\
\hline $5^{\text {th }}$ time & 2.0 & - & - & - \\
\hline $6^{\text {th }}$ time & 1.4 & - & - & - \\
\hline $\begin{array}{l}\text { Content of immuno- } \\
\text { globulins in colostrum, g } \\
\text { / 1: }\end{array}$ & & & & \\
\hline $1^{\text {st }}$ time & $58.94 \pm 0.73$ & $59.12 \pm 0.81$ & $58.76 \pm 0.84$ & $58.81 \pm 0.79$ \\
\hline $2^{\text {nd }}$ time & $42.18 \pm 0.66$ & $41.95 \pm 0.59$ & $42.10 \pm 0.63$ & $41.98 \pm 0.65$ \\
\hline $3^{\text {rd }}$ time & $35.10 \pm 0.54$ & $35.24 \pm 0.56$ & $34.98 \pm 0.47$ & - \\
\hline $4^{\text {th }}$ time & $28.30 \pm 0.45$ & $28.72 \pm 0.42$ & $28.56 \pm 0.43$ & - \\
\hline $5^{\text {th }}$ time & $26.73 \pm 0.32$ & - & - & - \\
\hline $6^{\text {th }}$ time & $21.48 \pm 0.27$ & - & - & - \\
\hline $\begin{array}{l}\text { Colostrum volume con- } \\
\text { sumed per day } 1\end{array}$ & 10.6 & 8.0 & 8.0 & 7.0 \\
\hline $\begin{array}{l}\text { Amount of immunoglob- } \\
\text { ulins consumed per day, } \\
\mathrm{g}\end{array}$ & $382.23 \pm 8.79$ & $330.06 \pm 9.31$ & $328.80 \pm 8.94$ & $352.80 \pm 10.11$ \\
\hline $\begin{array}{l}\text { Number of swallowing } \\
\text { movements when drink- } \\
\text { ing the first portion of } \\
\text { colostrum, times }\end{array}$ & $668 \pm 21.3$ & $593 \pm 19.4$ & $622 \pm 18.5$ & - \\
\hline
\end{tabular}

The 3.51 of colostrum given to the calf through the CalfDrenche system is determined by the abomasum capacity of the large Holstein calves.

It is known that after calving, the content of immunoglobulins in colostrum begins to decrease with each milking. Therefore, it is very important that calves receive at least $75 \mathrm{~g}$ of immunoglobulins with the first portion of milk. Scientists of Belarus have established that for the formation of colostral immunity in the body of newborns, $6.1 \mathrm{~g}$ of Ig per $1 \mathrm{~kg}$ of live weight must be supplied to their body with colostrum during the first day of life [15].

The research results showed that the largest amount of immunoglobulins (382.23 g) during the first day of life was received by calves with the sucking method of drinking colostrum. Difference in comparison with group II was $52.17 \mathrm{~g}(15.8 \%$; $\mathrm{P}<0.001)$, with group III - $53.43 \mathrm{~g} \mathrm{(16.3 \% ;} \mathrm{P}<0.001)$, with group IV - $29.43 \mathrm{~g}(8.3 \%$; $\mathrm{P}<0.05)$.

It was found that the calves with the sucking method consumed colostrum in smaller sips, which contributes to its better mixing with saliva in the oral cavity. The average sip size when the calf sucked colostrum from the udder was $1.95 \mathrm{~g}$, when fed from a suckling bottle $-3.37 \mathrm{~g}$, from a nipple pail $-3.21 \mathrm{~g}$. 
Immunoglobulins, getting into the bloodstream of the calf, create colostral (temporary) immunity in the body of the newborn. At the same time, A. Fox, A. Kleinsmith [1], S. Zarcula [13] note in their works that among calves of the Holstein breed, 23\% and more do not assimilate colostrum immunoglobulins and thus are doomed to death from infection. For the formation of immunity, as established by C. R. Baumrucker et al. [16], along with the quality of colostrum, a very important factor is the intensity of the transfer of immunoglobulins from colostrum to the blood serum of calves, especially in the first 6 hours after birth, while proteolytic enzymes in the small intestine are not yet functioning. It is also very important for the formation of immunity that 6 hours after drinking the first portion of colostrum, the content of immunoglobulins in the blood serum of calves should not be lower than $10 \mathrm{mg} / \mathrm{ml}$ (Table 2).

Table 2. Dynamics of immunoglobulins in the blood serum of newborn calves after feeding with colostrum, $\mathrm{mg} / \mathrm{ml}$.

\begin{tabular}{|c|c|c|c|c|}
\hline \multirow{2}{*}{$\begin{array}{c}\text { Time after } \\
\text { feeding with } \\
\text { colostrum, }\end{array}$} & \multicolumn{4}{|c|}{ Method of feeding with colostrum } \\
\cline { 2 - 5 } & $\begin{array}{c}\text { sucking } \\
\text { group I }\end{array}$ & $\begin{array}{c}\text { suckling bottle } \\
\text { group II }\end{array}$ & $\begin{array}{c}\text { nipple pail } \\
\text { group III }\end{array}$ & $\begin{array}{c}\text { CalfDrencher } \\
\text { group IV }\end{array}$ \\
\hline $\begin{array}{c}\text { Before colos- } \\
\text { trum intake }\end{array}$ & $0.14 \pm 0.03$ & $0.15 \pm 0.02$ & $0.13 \pm 0.01$ & $0.14 \pm 0.02$ \\
\hline 1 & $0.29 \pm 0.13$ & $0 . .24 \pm 0.15$ & $0.27 \pm 0.18$ & $0.19 \pm 0.15$ \\
\hline 2 & $2.48 \pm 0.29$ & $2.26 \pm 0.24$ & $2.28 \pm 0.31$ & $1.83 \pm 0.27$ \\
\hline 3 & $4.53 \pm 0.31$ & $3.51 \pm 0.28$ & $3.76 \pm 0.35$ & $2.98 \pm 0.42$ \\
\hline 4 & $5.82 \pm 0.37$ & $4.85 \pm 0.33$ & $5.12 \pm 0.40$ & $4.39 \pm 0.44$ \\
\hline 5 & $7.56 \pm 0.48$ & $6.59 \pm 0.42$ & $6.87 \pm 0.47$ & $6.18 \pm 0.51$ \\
\hline 6 & $11.19 \pm 0.53$ & $9.24 \pm 0.57$ & $9.50 \pm 0.54$ & $8.83 \pm 0.62$ \\
\hline 12 & $13.95 \pm 0.96$ & $11.86 \pm 0.89$ & $12.24 \pm 0.91$ & $10.59 \pm 1.12$ \\
\hline 24 & $22.38 \pm 0.89$ & $20.15 \pm 0.93$ & $20.42 \pm 0.97$ & $12.84 \pm 0.93$ \\
\hline 36 & $22.93 \pm 0.81$ & $20.46 \pm 0.88$ & $20.69 \pm 0.99$ & $15.34 \pm 0.96$ \\
\hline 48 & $23.24 \pm 0.84$ & $20.78 \pm 0.83$ & $20.95 \pm 0.98$ & $17.63 \pm 1.08$ \\
\hline 72 & $22.96 \pm 0.92$ & $20.65 \pm 0.87$ & $20.78 \pm 0.94$ & $18.56 \pm 1.12$ \\
\hline
\end{tabular}

The study of the dynamics of the content of immunoglobulins in the blood serum of newborn calves showed that, regardless of the method of feeding with colostrum, immunoglobulins begin to enter the bloodstream of the body one hour after drinking the first portion of colostrum. In this case, the intake of immunoglobulins with the suction method occurs more intensively. Six hours after drinking the first portion of colostrum, the content of immunoglobulins in the blood serum of calves of group I was more than of group II by $1.95 \mathrm{mg} / \mathrm{ml}(21.1 \% ; \mathrm{P}<0.05)$, group III - by $1.69 \mathrm{mg} / \mathrm{ml}(17.8 \% ; \mathrm{P}<0.05)$, group IV - by $2.36 \mathrm{mg} / \mathrm{ml}(26.7 \% ; \mathrm{P}<0.01)$.

An increase in the content of immunoglobulins in the blood serum of calves occurs during the first 48 hours after birth and reaches $23.24 \mathrm{mg} / \mathrm{ml}$ with the sucking method of drinking colostrum, which is more than in group II by $2.46 \mathrm{mg} / \mathrm{ml}(11.8 \%$; $\mathrm{P}<0.01)$, group III - by $2.29 \mathrm{mg} / \mathrm{ml}(10.9 \%)$, group IV - by $5.61 \mathrm{mg} / \mathrm{ml}(31.8 \%$; $\mathrm{P}<0.001)$. Starting from the third day of life, the content of immunoglobulins in the blood serum of calves starts to slightly decrease. This process is caused by the fact that on the third day after calving, the content of immunoglobulins in cow colostrum decreases by $50.07 \mathrm{~g} / 1(92.9 \%$; $<0.001)$ and is $3.85 \mathrm{~g} / \mathrm{l}$, including $\mathrm{IgG}-0.08 \mathrm{~g} / \mathrm{l}$, IgA - $3.05 \mathrm{~g} / \mathrm{l}$, IgM - $0.72 \mathrm{~g} / \mathrm{l}$. In addition, the permeability of the intestinal walls stops, and the transfer of immunoglobulins from colostrum to the blood ends completely 36 hours after the birth of the calf. As a result, the flow of immunoglobulins into the blood of the calf with colostrum stops, and other protective mechanisms of the body have not yet completed their formation and will begin to fully function only on the 15-20th day of life. Therefore, this period is the most dangerous for the health of the calf. 
Particular attention should be paid to how the formation of the immune status in calves occurs when feeding with colostrum using the CalfDrencher system. The system involves pouring colostrum through a rigid catheter into the calf's abomasum. In this case, the digestion process is completely disrupted. It is known fact that in newborn calves, the act of sucking, which takes place reflexively, triggers the entire digestive mechanism. Drenching completely eliminates the first and very important phase of the digestion process fermentation in the oral cavity, as a result of mixing colostrum with saliva. Besides, the saliva of the calves contains lipolytic enzymes that break down the milk fat extensively present in colostrum. According to scientists from Belarus [15], when colostrum is sucked out of the udder, it enters the calf's abomasum in small portions, it coagulates under the action of gastric juice with the formation of a loose curd mass and undergoes enzymatic processing. Colostrum serum released at the same time contains up to $83 \%$ of immunoglobulins supplied with colostrum. The serum passes into the small intestine, where it is absorbed into the bloodstream, forming colostral immunity.

If colostrum is consumed by the sucking method, the calf divides it into small portions of 2-3 g with swallowing movements, then when drenching, the colostrum enters the abomasum in a continuous flow. As a result, under the action of hydrochloric acid of gastric juice, colostrum casein coagulates, forming a dense homogeneous clot, disrupting the digestion process and preventing the separation of rennet. Ultimately, the proportion of immunoglobulins entering the bloodstream is significantly reduced.

Disturbances in the process of digestion during drenching led to the fact that during the first day of life, which are fundamental for the health, growth and development of newborn calves, their body absorbed immunoglobulins by $9.54 \mathrm{mg} / \mathrm{ml}(42.6 \% ; \mathrm{P}<0.001)$ less than in the case of the suction feeding method.

Analysis of the intensity of the transition of immunoglobulins from colostrum into the blood of calves in the first 6 hours after feeding showed that this indicator largely depends on the method of feeding (Table 3).

Table 3. The intensity of the transition of immunoglobulins from colostrum into the blood of calves in the first 6 hours after feeding.

\begin{tabular}{|l|c|c|c|c|c|c|c|c|}
\hline \multirow{2}{*}{$\begin{array}{c}\text { Content of im- } \\
\text { munoglobulins in } \\
\text { the blood, } \mathrm{mg} / \mathrm{ml}\end{array}$} & \multicolumn{9}{|c|}{$\begin{array}{c}\text { sucking } \\
\text { group I }\end{array}$} & \multicolumn{2}{c|}{$\begin{array}{c}\text { suckling bottle } \\
\text { group II }\end{array}$} & \multicolumn{2}{c|}{$\begin{array}{c}\text { nipple pail } \\
\text { group III }\end{array}$} & \multicolumn{2}{c|}{$\begin{array}{c}\text { CalfDrencher } \\
\text { group IV }\end{array}$} \\
\cline { 2 - 9 } & heads & $\%$ & heads & $\%$ & heads & $\%$ & heads & $\%$ \\
\hline Up to 4.0 & - & - & 1 & 6.7 & - & - & 2 & 13.3 \\
\hline $4.1-6.0$ & 1 & 6.7 & 1 & 6.7 & 2 & 13.3 & 2 & 13.3 \\
\hline $6.1-8.0$ & 1 & 6.7 & 3 & 20.0 & 2 & 13.3 & 3 & 20.0 \\
\hline $8.1-10.0$ & 2 & 13.3 & 6 & 40.0 & 5 & 33.5 & 5 & 33.4 \\
\hline $10.1-12.0$ & 7 & 46.7 & 4 & 26.6 & 4 & 26.6 & 3 & 20.0 \\
\hline Mora than 12.0 & 4 & 26.6 & - & - & 2 & 13.3 & - & - \\
\hline
\end{tabular}

As noted above, for the formation of a full-fledged colostral immunity in the body, it is necessary that the content of immunoglobulins in the blood serum was at least $10 \mathrm{mg} / \mathrm{ml} 6$ hours after the first portion of colostrum was given to the calves. It was found that in the group of calves with the suckling method of feeding with colostrum, there were $73.3 \%$ of such animals, when drinking from a suckling bottle - $26.6 \%$, from a nipple pail $-39.9 \%$, using the CalfDrencher system - 20.0\%.

Since calves, in whose blood serum the content of immunoglobulins does not exceed $6.0 \mathrm{mg} / \mathrm{ml} 6$ hours after the first feeding with colostrum, in $100 \%$ of cases die from various diseases, they can be attributed to the group that do not assimilate colostrum immunoglobulins. There were $6.7 \%$ of such calves in group I, in group II - $13.4 \%$, in group III $-13.3 \%$, in group IV $-26.6 \%$. Calves, whose serum levels of immunoglobulins reach 
6.1-10.0 $\mathrm{mg} / \mathrm{ml}$, are at risk and require careful care, good housing conditions and optimal microclimate parameters.

Considering that the calves in the experimental groups were of the same breed, were selected according to live weight, the colostrum of mother cows had approximately the same quality, it can be assumed that the intensity of the transfer of immunoglobulins from colostrum to the blood and, as a consequence, the incidence of calves were decisively influenced by the method of feeding with colostrum and the accompanying features of the digestion physiology (Table 4).

Table 4. The incidence of calves in the first month after birth.

\begin{tabular}{|l|c|c|c|c|c|c|c|c|}
\hline \multirow{3}{*}{ Calf age, days } & \multicolumn{9}{|c|}{ Method of feeding with colostrum } \\
\cline { 2 - 10 } & \multicolumn{2}{|c|}{$\begin{array}{c}\text { sucking } \\
\text { group I }\end{array}$} & \multicolumn{2}{c|}{$\begin{array}{c}\text { suckling bottle } \\
\text { group II }\end{array}$} & \multicolumn{2}{c|}{$\begin{array}{c}\text { nipple pail } \\
\text { group III }\end{array}$} & \multicolumn{2}{c|}{$\begin{array}{c}\text { CalfDrencher } \\
\text { group IV }\end{array}$} \\
\cline { 2 - 10 } & heads & $\%$ & heads & $\%$ & heads & $\%$ & heads & $\%$ \\
\hline $1-5$ & - & - & 3 & 20.0 & 1 & 6.7 & 5 & 33.3 \\
\hline $6-10$ & 1 & 6.7 & 3 & 20.0 & 2 & 13.3 & 3 & 20.0 \\
\hline $11-15$ & 1 & 6.7 & 1 & 6.7 & 1 & 6.7 & 2 & 13.3 \\
\hline $16-20$ & 1 & 6.7 & 1 & 6.7 & 2 & 13.3 & 1 & 6.7 \\
\hline $21-30$ & - & - & 1 & - & - & - & - & - \\
\hline $\begin{array}{l}\text { Total for a } \\
\text { month }\end{array}$ & 3 & 20.1 & 8 & 53.4 & 6 & 40.0 & 11 & 73.3 \\
\hline
\end{tabular}

According to the data of domestic and foreign scientists $[4,9,10,17]$, the most dangerous for the health of newborn calves is the period of the first two weeks of their life, while the body is forming permanent immunity. Studies have shown that, depending on the way colostrum was fed, the incidence of calves in the groups was different. In the first 5 days of life, with the suckling method of drinking milk, not a single calf got sick, when drinking from a suckling bottle - 3 calves got sick (20.0\%), from a nipple pail - 1 calf (6.7\%), using the CalfDrenche system - 5 calves (33.3\%). In the period from 6 to 10 days of life, there was 1 sick calf $(6.7 \%)$ in group I, in group II - 3 calves $(20.0 \%)$, in group III - 2 calves (13.3\%), in group IV - 3 calves $(20.0 \%)$. In just a 15 -day period, which is critical for newborns, 2 calves (13.3\%) fell ill in group I, in group II - 7 (46.7\%), group III - 4 (26.7\%), group IV - $10(66.6 \%)$, and for the first month of life of calves, the incidence in the groups was $20.1 ; 53.4 ; 40.0 ; 73.3 \%$, respectively.

The main indicator of the effectiveness of the use of different methods of feeding newborn calves with colostrum is their growth rate during the rearing period (Table 5).

Table 5. Dynamics of live weight of Holstein heifers with age, $\mathrm{kg}$.

\begin{tabular}{|c|c|c|c|c|}
\hline \multirow{2}{*}{ Calf age, months } & \multicolumn{4}{|c|}{ Method of feeding with colostrum } \\
\cline { 2 - 5 } & $\begin{array}{c}\text { sucking } \\
\text { group I }\end{array}$ & $\begin{array}{c}\text { suckling bottle } \\
\text { group II }\end{array}$ & $\begin{array}{c}\text { nipple pail group } \\
\text { III }\end{array}$ & $\begin{array}{c}\text { CalfDrencher } \\
\text { group IV }\end{array}$ \\
\hline Newborn & $39.0 \pm 0.41$ & $38.8 \pm 0.53$ & $39.2 \pm 0.44$ & $39.5 \pm 0.38$ \\
\hline 1 & $67.9 \pm 0.93$ & $60.9 \pm 0.70$ & $62.4 \pm 0.67$ & $57.4 \pm 0.87$ \\
\hline 2 & $99.3 \pm 1.34$ & $88.9 \pm 1.45$ & $91.0 \pm 1.23$ & $83.5 \pm 1.69$ \\
\hline 3 & $126.2 \pm 1.59$ & $113.4 \pm 2.03$ & $116.3 \pm 1.84$ & $106.4 \pm 2.43$ \\
\hline 4 & $154.3 \pm 2.25$ & $137.3 \pm 2.31$ & $140.7 \pm 2.09$ & $128.7 \pm 2.86$ \\
\hline 5 & $179.1 \pm 2.82$ & $160.5 \pm 2.64$ & $164.4 \pm 2.38$ & $149.4 \pm 3.21$ \\
\hline 6 & $202.6 \pm 3.36$ & $182.6 \pm 3.12$ & $187.1 \pm 2.83$ & $169.1 \pm 3.74$ \\
\hline 9 & $272.2 \pm 3.79$ & $251.0 \pm 3.56$ & $256.4 \pm 3.45$ & $235.1 \pm 4.22$ \\
\hline 12 & $337.4 \pm 4.28$ & $313.9 \pm 3.81$ & $320.6 \pm 3.98$ & $295.6 \pm 4.57$ \\
\hline 15 & $399.3 \pm 4.67$ & $374.7 \pm 4.49$ & $382.2 \pm 4.72$ & $355.0 \pm 5.18$ \\
\hline 18 & $456.2 \pm 5.37$ & $428.2 \pm 5.63$ & $436.5 \pm 6.12$ & $407.8 \pm 6.21$ \\
\hline First-calving cows & $576.3 \pm 8.21$ & $534.6 \pm 7.95$ & $539.4 \pm 7.88$ & $524.7 \pm 8.69$ \\
\hline
\end{tabular}


It was found that, depending on the method of feeding with colostrum, the growth and development of calves in groups had their own characteristics. The highest growth rate was observed in the 1 st group of calves, which were fed with the nursing cows by the regulated suckling method, and the lowest - in calves, which were injected with colostrum using the CalfDrencher system. Average daily gains in live weight of calves of group I in the first month of life amounted to $963.3 \mathrm{~g}$, which is more than in group II by $226.6 \mathrm{~g}(30.8 \%)$, group III - by $190.0 \mathrm{~g}(24.6 \%)$, group IV - by $366.6 \mathrm{~g}(61.4 \%)$. In the second month of life, the calves showed the highest average daily gains, regardless of the method of feeding with colostrum. In calves of group I, they amounted to $1046.7 \mathrm{~g}$, which is more than in group II by $113.4 \mathrm{~g}(12.2 \%)$, in group III - by $93.4 \mathrm{~g}(9.8 \%)$, in group IV - by $178.0 \mathrm{~g}(20.5 \%)$. Thus, it can be assumed that the body of calves, due to its internal reserves, is trying to compensate for the growth retardation from the norm, genetically determined by the characteristics of the breed, which was caused by violations associated with the technology and methods of feeding with colostrum.

In accordance with the technology adopted in the farm, at the age of 2 months, calves are united in groups by 10 heads, and dairy feed is completely excluded from the diet. This is a significant stress for the young animals, which negatively affects the growth rate. At the same time, the average daily gains in live weight decrease in the $3 \mathrm{rd}$ month of calf life by groups by $110.0 \mathrm{~g}(10.5 \%), 116.6 \mathrm{~g}(12.5 \%), 110.0 \mathrm{~g}(11.5 \%), 104.0 \mathrm{~g}(12.0 \%)$, respectively.

Differences in the intensity of growth led to the fact that at the age of 6 months, heifers of group I surpassed in live weight their herdmates from group II by $20.0 \mathrm{~kg}(11.0 \%$; $\mathrm{P}<0.001)$, group III - by $15.5 \mathrm{~kg}(8.3 \% ; \mathrm{P}<0.01)$, group IV - by $33.5 \mathrm{~kg}(19.8 \% ; \mathrm{P}<0.001)$. At the age of 12 months, the difference between the groups was $23.5 \mathrm{~kg}(7.5 \% ; \mathrm{P}<0.001)$; $16.8 \mathrm{~kg}(5.2 \% ; \mathrm{P}<0.01) ; 41.8 \mathrm{~kg}(14.1 \% ; \mathrm{P}<0.001)$, at the age of 18 months $-28.0 \mathrm{~kg}$ $(6.5 \% ; \mathrm{P}<0.01) ; 19.7 \mathrm{~kg}(4.5 \% ; \mathrm{P}<0.05) ; 48.4 \mathrm{~kg}(11.9 \% ; \mathrm{P}<0.001)$, respectively.

The results of the studies showed that despite the fact that the growth intensity in animals in groups is almost equalized by the age of 9 months, they fail to compensate for the lag from heifers of group I in the previous period. During the period from 18 months of age to the first calving, the live weight of heifers in groups increases by another $120.1 \mathrm{~kg}$ (26.3\%), $106.4 \mathrm{~kg}(24.8 \%), 102.9 \mathrm{~kg}(23.6 \%), 116.9 \mathrm{~kg}(28.7 \%)$. Moreover, if one follows the instructions to milk 8 thousand $\mathrm{kg}$ of milk or more from a cow for lactation, the live weight of Holstein heifers should be not less than $180 \mathrm{~kg}$ at the age of 6 months, 12 months - $310 \mathrm{~kg}, 18$ months - $420 \mathrm{~kg}$, and first-calving cows - 540-550 kg. In this case, heifers of group I reach the live weight of $420 \mathrm{~kg}$ required for the first fertilization at the age of 16 months, group II - 18 months, group III - 17 months, group IV - 19 months.

\section{Conclusion}

Based on these studies, it can be concluded that the best results in rearing replacement heifers were obtained when using the sucking method of feeding calves with colostrum and milk in the first two months of their life. If the farm puts the marketable value of milk on the first place by limiting the use of whole milk, then we can recommend the method of feeding with colostrum and milk using a nipple pail. But at the same time, heifers will reach the live weight necessary for the first insemination at the age of 17 months. For feeding calves that do not have a sucking reflex in the first hours of life with colostrum, it is possible to use the CalfDrencher system. But it is not recommended to massively introduce this technology and feed all newborns using this method. 


\section{References}

1. A. Fox, A. Kleinsmith, Scientific and medical research related to bovine colostrums. Its relationship and use in the treatment of disease in humans. Selected publishers' abstracts (2010) http://www.immunetree.com

2. S. Patel, J. Gibbons, D.C. Wathes, Ensuring optimal colostrum transfer to newborn dairy calves, Cattle Practice 22 (1), 95-104 (2014)

3. J.D. Quigley, A. Lago, C. Chapman, P. Erickson, J. Polo, Evalution of the Brix refractometer to estimate immunoglobulin $G$ concentration in bovine colostrums, J. Dairy Sci. 96, 1148-1155 (2013)

4. R.R. Sakai, D.M. Coons, M. Chigerve, Effect of single oroesophageal feeding of $3 \mathrm{~L}$ versus $4 \mathrm{~L}$ colostrum on absorbtion of colostral IgG in Holstein bull calves, Livestock Science 148, 296-299 (2012)

5. J.L. Johonson, S.M. Gooden, T. Molitor, T. Ames, D. Hagman, Effect of feeding heattreated colostrum on passive transfer of immune and nutritional parameters in neonatal dairy calves, J. Dairy Sci. 90, 5189-5198 (2007)

6. T. Mejer, Bovine colostrum and factors impacting colostrum quality in conventional and organic dairy herds (Aarhus University, 2015)

7. P.P. Pithua, S.S. Aly, A cohort study of the association between serum immunoglobulin $G$ concentration and preweaning health, growth, and survival in Holsten calves, Intern. J. Appl. Res. Vet. Med. 11, 1, 77-83 (2013)

8. S.D. Batanov, O.S. Starostina, I.A. Baranova, Genetic parameters of productivity and exterior traits of dairy cattle, IOP Conference Series: Earth and Environmental Science 548(3), 032023 (2020) DOI: 10.1088/1755-1315/548/3/032023

9. Technological requirements for rearing calves: recommendations, Ministry of Agriculture and Food of the Republic of Belarus, Minsk: Journal "Belarusian Agriculture" (2014)

10. J.D. Quigley, Passive immunity in newborn calves (2010) http://www.weds.ca

11. I.R. Tizard, Immunity in the fetus and newborn, Veterinary Immunology, Ninth edition, Elsevier 225-239 (2013)

12. A.W. Scammell, Production and uses of colostrum, Austr. J. Dairy Techn. 56(2), 74-82 (2001)

13. S. Zarcula, H. Cemescu, C. Mircu. C. Tulcan, et.al., Influence of breed, parity and food intake on chemical composition of first colostrum in cow, Anim. Sci. Biotechn. 43(1), 154-157 (2010)

14. A.K. Singh, S. Pandita, M.M. Vaidya, et al. Bovine colostrum and neonate immunity A Review, Agri. Review 32, 2, 79-90 (2011)

15. Colostrum, Colostrum immunoglobulins, The quality and norms of feeding newborn calves with colostrum: scientific and practical recommendations (Grodno: GGAU. 2010)

16. C.R. Baumrucker, A.M. Burkett, A.L. Magliaro-Macrina, C.D. Dechow, Colostrogenesis: Mass transfer of immunoglobulin G1 into colostrum, J. Dairy Sci. 93(7), 3031-3038 (2010) 